Jie Chen and Fulong Wu (2020) Housing and land financialization under the state ownerhship of land in China. Land Use Policy.

final accepted version: https://doi.org/10.1016/j.landusepol.2020.104844

\title{
Housing and land financialization under the state ownership of land in China
}

\begin{abstract}
By studying the case of China's state land ownership regime, this paper examines the financialization of housing and land and illustrates how these processes are intertwined and reinforce each other. This paper reached three conclusions: first, housing financialization and land financialization cannot be separated in China; housing financialization boosts the demand for housing assets and land financialization speeds up the supply to meet the demand. Second, housing financialization and land financialization jointly expand the production of properties and sustain capital accumulation. Third, the financialization of land and housing evolve over time. We conclude that the separate and related processes of housing and land financialization in China reflect the unique characteristics of the state ownership of land in China.
\end{abstract}

Key Words: Financializaton; assetization; capitalization; housing; land; China

\section{Introduction}

Although there are numerous investigations on the financialization of housing (Gotham, 2009; Fernandez and Aalbers, 2016; García-Lamarca and Kaika, 2016; Aalbers, 2017) or on the financialization of land (Kaika and Ruggiero, 2016; Christophers, 2017), in the case of Western economies it is not necessary to discuss the two processes separately in most instances, as housing and land are institutionally inseparable. However, in China, because of the state ownership of land, housing and land financialization are separate yet related processes. Using the case of China's state 
ownership of land, this paper illustrates the specificity of China's financialization processes. China is perhaps the best context to study the interplay of housing financialization and land financialization, as both housing and land have been transformed from non-tradable goods that were allocated by the state, into tradable commodity goods and then investable assets, within roughly three decades.

This paper also contributes to the literature by showing how financialization is occurring and evolving under state entrepreneruialism. This makes it a useful addition to the financialization literature, as most existing studies of financialization phenomena are conducted within the context of market capitalist economies (Froud et al., 2000; Martin, 2002; Krippner, 2005). Meanwhile, China is also often portrayed as an emblematic entrepreneurial state (Duckett, 1996; Xue and Wu, 2015), and it has been suggested that the Chinese state's entrepreneurial nature is largely built on its monopolistic power to dispose urban land use-rights when governing urban transformations (Shin, 2009; Wu, 2018). Analysing the instrumental roles of China's state in promoting the financialization of urban space would provide new understandings of the interactive relationships between the state and market in the stateled accumulation regime.

Our analysis endeavours to link global trends with the China-specific financialization trajectory regarding housing and land, or more generally, urban space. A proliferating literature has emerged to analyse the financialization of urban space, but most studies are based on rather similar backgrounds in the Western capitalist economies (Weber, 2010; Bonizzi, 2013; Buckley and Hanieh, 2014). The present work thus contributes to verifying the hypothesis that the variety of housing financialization is both pathdependent and context-specific (Aalbers, 2017). We nonetheless continue to stress that the forms of financialization used in China differ across different types of land: specifically, only land for commercial and residential use has been capitalized, while land for industrial use is solely commodified.

By analysing the interplay between housing financialization and land financialization in China, this paper has three major findings. First, housing financialization and land financialization are inherently intertwined. Housing financialization boosts the demand for housing assets, and land financialization speeds up the supply to meet such demand. 
Second, housing financialization and land financialization jointly expand the production of urban space and then promote capital accumulation. Third, the financialization of the housing-land regime can evolve under state land ownership. That is to say, private ownership is not a precondition for financialization, provided that ownership rights can be separated from use-rights. What financialized is not the property per se but the rights to use it.

In addition, we stress that the process and forms of the financialization of housing and land in China should be understood by the Chinese style of state entrepreneurialism (Wu, 2018). The "shareholding state" is increasingly resorting to financial means to manage its ownership, accumulate its assets and fund public investment (Wang, 2015). The "performance-based legitimacy" requires the state to create economic prosperity (Yang and Zhao, 2015). However, while the state actively uses market instruments to promote economic growth, it has its own policy agenda (Wu, 2018). Therefore, financialization might not be the policy aim but rather a result of interwined processes of the production of housing and land properties. In this regard, financialized state entrepreneurialism goes beyond the notion of financialized entrepreneurial governance because the former uses financial instruments to achieve its governance while the latter is being financialized into a financial form of economic management $(\mathrm{Wu}, 2018)$. This active use of the financial method by the state as a development strategy can be seen in the process of land-riven financialization ( $\mathrm{Wu}, 2019)$. The changing pattern of the interplay between housing financialization and land financialization best epitomizes this point.

\section{The financialization of housing and land: concepts and related literature}

In this section, we first provide a brief discussion of key concepts used in this paper, then we examine the Chinese speciality of housing-land financialization, and end by pointing out the research gaps in the relevant literature.

Although the financialization thesis has been discussed in a wide array of disciplines since the 1980s, the exact meaning has not yet resulted in a widely accepted consensus. In the existing literature, the term "financialization" has been used to refer to one of the following four phenomena: the growing importance of finance in the national economy 
(Epstein, 2005); a changing regime of accumulation (Krippner, 2005); the rise of shareholder value in corporation governance (Froud et al., 2000); or the increasing financialization of everyday life, and indeed almost everything (Martin, 2002; Montgomerie, 2007). For example, it is argued that financialization is a process to promote a new pattern of capital accumulation, where "profit accrues primarily through financial channels rather than through trade and commodity production" (Krippner 2005: 174).

Notably, Henri Lefebvre comments that financialization is the increasing capability of capital to incessantly transform material-use values into immaterial exchange values (and back again) (Lefebvre, 1991). Krippner (2015) defines financial activities as "the provision (or transfer) of capital in expectation of future interests, dividends, or capital gains.” (pp. 174-175). From this perspective, money is just a medium of capital circulation. The capitalist process of production is generally intended for capital accumulation.

Housing, by its nature, has use-value and exchange value; it has thus long been considered the most prominent subject of financialization (Gotham, 2006, 2009; Aalbers and Christophers, 2014). The literature has proposed to understand housing financialization as a process where the use value of housing services is increasingly accumulated and traded in financial markets with enhanced liquidity (Gotham, 2006, 2009).

In a broad perspective, the "urbanization of capital" absorbs the surplus of capital and defers the fall of capital's profit rate (Harvey, 1985). Despite significant attempts to understand how the real estate sector is absorbing the surplus capital of the primary circuit (Aalbers, 2008; Fernandez and Aalbers, 2016), the role of housing in accumulating capital is still not clearly understood. This is somewhat surprising, as financialization is often understood as existing where capital accumulation occurs more through financial channels than through commodity production and trade (Boyer, 2000; Krippner, 2005).

Housing and land can play specific roles in capital accumulation. Although leveraged debt financing is widely used in the economy, the expansion of capital accumulation 
through borrowing future income with good protection against default of future debt payment can thrive only in the real estate sector, where spatially fixed and longenduring property that produces "strategic fix income" can be used as "high-quality collateral" (Aalbers, 2017). The literature has long noticed that housing is used as a tool to promote capital accumulation and then a means to drive urban development and economic growth, especially in East Asian developmental states (Doling and Ronald, 2014). Recently, the literature has begun to note that states in Western advanced capitalist economies such as the USA and UK are also mobilizing capital in the capital market through the "assetization" of land (Christophers, 2017; Ward and Swyngedouw, 2018). However, while the discussions on how the commodification and financialization of land contribute to local public finance and capital accumulation in China are extensive (Lin and Yi, 2011; Pan et al., 2017; Wu, 2019), the role of housing financialization in the capital accumulation in China has only been recently discussed (Wu, 2015; Shen and Wu, 2017; Wu et al. 2020).

Nonetheless, a financialized housing market has the result that both the supply of and demand for housing become increasingly determined by the exchange value rather than the use-value of housing. For example, one may understand "financial institutions mobilising mortgages as a speculative form of rent, and land and housing titles given to 'homeowners' as claims on their future labour" (García-Lamarca and Kaika, 2016: 319). When the housing-land regime becomes financialized, both housing and land become "financially exploitable" assets that are increasingly governed by the speculative nature of financial capital, and then become deeply involved in the process of capital accumulation and switching.

The interplay between housing financialization and land financialization in China has so far received little attention, let alone how such interplay evolves under the context of state ownership of land. To bridge these research gaps, we closely relate housing financialization and land financialization to the topic of capital accumulation.

\section{Analytical framework}

In this paper we try to distinguish different stages of financialisation through commodification, assetization and, ultimately, capitalization. "Commodification" is a 
process that makes originally non-tradable goods tradable by realizing their material use value as immaterial exchange value; "assetization" stresses converting a commodity into a financial asset that can expect future value appreciation; and "capitalization" is the transformation of future use value into current exchange value, which can be used in the present to produce next-stage use value (Wu et al., 2020). According to this interpretation, both assetization and capitalization are advanced stages of financialization, but assetization mainly relates to the household side, while capitalization is generally found in the production process. With the penetration of financial instruments, commodities with enduring use value become investable assets purchased either by households (motivated to accumulate wealth by making profits from future value appreciation of assets) or by firms (capitalizing the future value appreciation of assets as investable funds). Thus, by understanding "capital" as not just investable value that was stored in the past, but also as investable value that borrows from the future via financial instruments, we propose that capitalization can also be understood as the process of converting the future expected income streams of an asset into a financing source that enables use-value production in the present (Krippner, 2005; Weber, 2010; Birch, 2017; Ouma, Johnson and Bigger, 2018; Ryan-Collins, 2020). For example, as argued by Ryan-Collins, the emergence of a feedback cycle between finance and landed property is largely built on the capability of mortgage finance to borrow against the future appreciation value of collateralized property, in order to fund today's consumption (Ryan-Collins, 2020). Hence, this paper seeks to provide more detailed investigations regarding how the utilization of financial instruments has affected capital accumulation in the Chinese housing-land sector.

First, the money-capital supplied by financial institutions is based on the assetization or capitalization of future income streams. We use the term "money-capital" (Arrighi, 1994; Lapavitsas, 2011) to emphasize that the financial capital or credit provided by financial institutions are virtually playing intermediate roles in capital circulation. At first glance, it appears that development loans are collateralized on land (or land userights) and mortgage loans are collateralized on the physical form of housing (or its use-rights). However, with deeper scrutiny, one can find that development loans are essentially pledged on the capitalization of expected future income cash flows from developers' sale of housing projects, and mortgage loans are essentially secured on the assetization of the expected future market value of housing's use value. This perception 
is widely acknowledged in the practices and literature of real estate finance, but has received additional attention in the literature of financialization. The observation that all borrowers' financing of their current purchasing is eventually derived from their future income streams reckons the argument that the financialization of urban space, in forms such as Tax Increment Financing (TIF), is merely "selling city futures" (Weber, 2010: 251).

Second, financialization, particularly the capitalization of future income streams in the present, could promote capital accumulation. Although money-capital seems to play only an intermediate role in value circulation, the extent to which the realization of usevalue production or use-value consumption can be achieved today is contingent on how much the future use-value can be "monetized" as money-capital available for use today. Whenever the financing costs of borrowed money-capital are lower than the future financial returns of un-leveraged production, i.e. using only equity capital (the stored value that produced previously), leveraged producers can earn "leverage benefits" and are able to produce greater use values with same equity capital. Regarding financialization as "making profits through financial channels rather than production and trade" (Krippner, 2005) is prone to produce a misunderstanding - namely, that financialization merely involves redistributing the profits, but without producing new profit or new use-value. However, "developing by borrowing" is not always just an illusion (Pan et al., 2017). Financialization, through financial operations or "operations of capital" to fund production by borrowing against future value appreciation (Weber, 2010; Ouma, Johnson and Bigger, 2018), could expand the production of use-value via the mechanism of overcoming the liquidity constraints on production, or by improving the allocation efficiency of production factors.

Third, housing assetization and land capitalization are related. Here we take the proposition that the essence of housing consumption is consuming a housing service, including both the service flows derived from the habitat function of the housing building, and the location-specific urban amenity (Rouwendal, 1998). As the locationspecific amenity constitutes the basis of "land rent" (Ward and Aalbers, 2016), the consumption of a housing service always includes the consumption of "land rent"; and thus we refer to the integrated housing-land use-value as "urbanized use-value" in this paper. Therefore, on the one hand, the assetization of housing services must involve the 
capitalization of "land rent", and on the other, the capitalization of "land rent" will be facilitated if housing service has been converted to liquid financial assets.

\section{The stages of financialization of housing and land in China}

Based on the interplay relationship between different forms of housing financializaton and land financialization, four stages of the financialization of the housing-land regime are proposed. Notably, the four stages do not evolve in a strictly sequential order, whereby one stage emerges only after the previous stage has completely ended, but instead they proceed with significant overlapping of time.

\subsection{Housing commodification without land commodification (1978-1987)}

In Maoist China, welfare-form public rental housing became the predominant form of housing provision, and land was allocated to working units for an indefinite period. The de-commodification of housing and land, an embodiment of the centrally planned economy, is said to have been shaped by both ideological considerations and development strategy reasons (Chen and Han, 2014). Initially, under the mounting pressures of both a housing shortage and soaring fiscal burdens on the welfare housing system in urban areas, and later in an attempt to solve the general incompatibility of the welfare housing system with a more liberalized economic system (Wang and Murie, 1996), the Chinese government advanced the reform of the urban housing sector; this was one of the first reforms in the general economic transition, launched in 1978. A series of pilot programmes had been implemented to promote the commodification of urban housing provision (Wang and Murie, 1996).

Despite the experiments for the commodification of public housing in the 1980s, the welfare housing system could not be terminated; this was due to several reasons, including affordability constraints under the low-wage system, as well as the lack of an accessible housing finance system (Wang and Murie, 1999). The concept that housing can be a commodity good became gradually accepted in Chinese society, and urban households were contributing much more than before to housing consumption.

Notably, in the Special Economic Zone of Shenzhen, the first commodity housing neighbourhood in the history of the PRC was started in 1979, and the first real estate 
company was set up in 1980 (Bian, 2010). However, China's 1982 Constitution banned any transfer of land use-rights. Thus, the commodification of urban land at nationwide scale was halted.

\subsection{Housing commodification accompanied by land commodification (1988-1997)}

Supported by the use-rights of urban land becoming legally tradable in 1988, a small but booming commodity housing market emerged and steadily expanded in China in the 1990s. Nevertheless, a dual-track system persisted in both the housing and land sectors in China until the late 1990s.

\section{Land commodification}

The first open-market conveyance of land use-rights was conducted in Shenzhen in September 1987, for two parcels of residential land (Qun, Li and Yan, 2015). Pilot experiments to increase the transferability of land use-rights in the free market were later conducted in a few other cities (Wu et al., 2014). However, a nationwide land market was set up only after March 1988 - the time when China's Constitution was amended to legalize the paid transfer of use-rights of state-owned land, and the Land Administration Law was correspondingly amended in the same year. The land userights could now be either sold by the local state on the so-called "first-hand land market", or transferred and traded between use-rights owners on the "second-hand land market" (Ding, 2003). For local states, the commodification of land soon became an important means of generating revenue. Thus, the nationwide legal commodification of land use-rights paved way for the large-scale development of commodity housing in China.

The Chinese state formally adopted the transformation of the planned economy to a market economy, in the form of the roadmap of economic transition, presented at the $14^{\text {th }}$ CCP national congress in October 1992 . This immediately spurred mounting demand for construction land in the cities. The importance of land assets to local states was raised, especially after the 1994 tax-sharing reform when the central state took away most tax revenues (Wang and Ye, 2016; Pan et al., 2017). While in 1988, only 118 lots of land with an area of 389 hectares were conveyed, with a revenue of 416.2 
million Yuan, in 1994 the use-rights transaction of 97,405 lots of land, with an area of 3,296 hectares, contributed a revenue of 35.9 billion Yuan and amounted about $20 \%$ of local states' fiscal income (Ding, 2003). The term "land finance" was created in this period, to refer to the sale revenue of land use-rights (Huang and Chan, 2018); but land development can also contribute revenue to local states through various forms of landrelated tax.

\section{The final triumph of housing commodification}

The total sale space of commodity housing that was built for sale expanded rapidly since the late 1980s: it rose from 18.35 million $\mathrm{m}^{2}$ in 1986 to 38.12 million $\mathrm{m}^{2}$ in 1992 (see Figure 1). However, even after the year 1992, when the market-oriented economic transition strategy had been formally adopted by the central state, a dual-track system persisted in the Chinese housing sector until the late 1990s. Until the mid-1990s, most new commodity housing was not bought by individuals, but instead bought by work units and then leased to their employees. The Urban Household Survey (UHS) database also shows that in the mid-1990s, public housing tenants still comprised about $65 \%$ of households in urban China. Besides the disincentives against accessing cheap public welfare housing that still dominated in the urban housing provision, the lack of financing means for housing purchase was also a major obstacle preventing Chinese households from purchasing a home of their own (Wang and Murie, 1999).

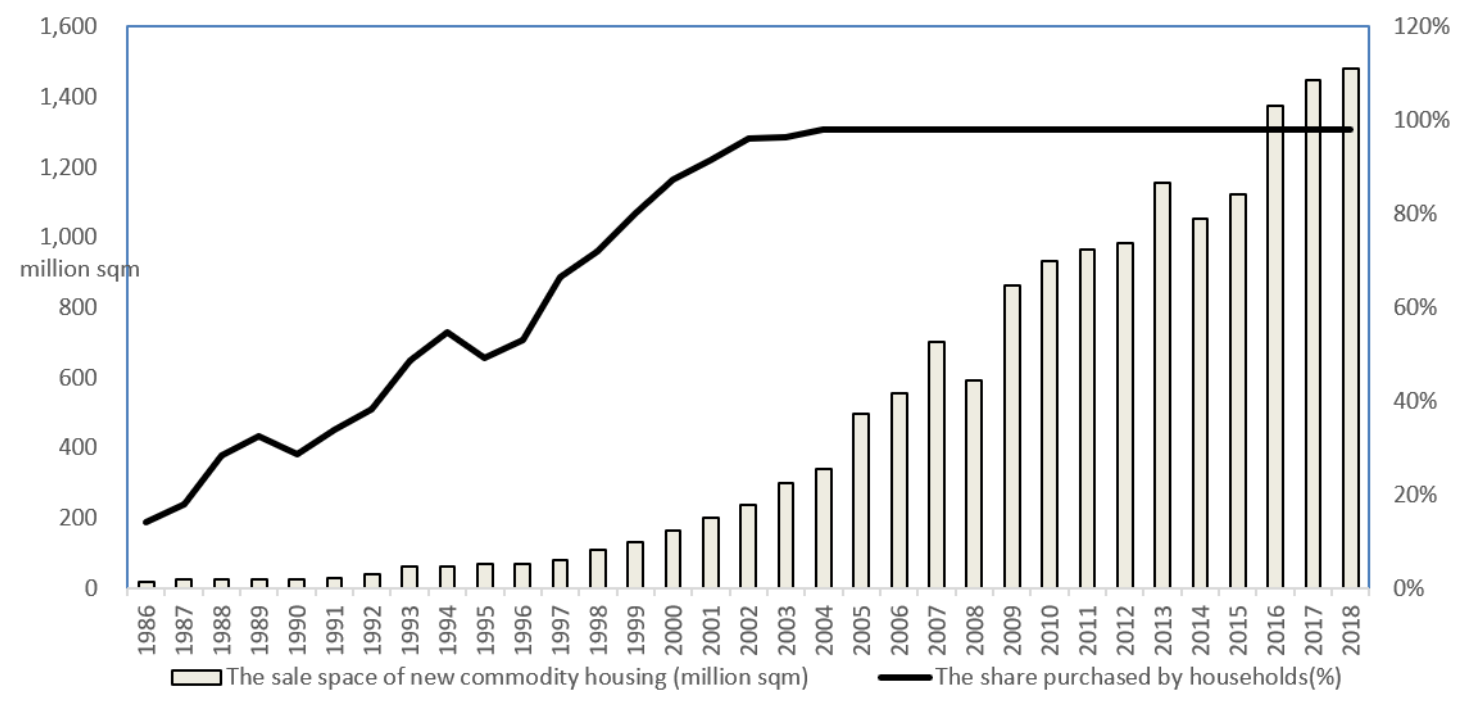

(Figure 1: The Commodity Housing Market in China (1986-2018))

Source: China Statistics Yearbook of the National Bureau of Statistics of China (NBSC) 
As early as the mid-1990s, the Chinese state realized that merely converting housing into a tradable commodity might not be enough to boost sufficient demand for housing (Wang and Murie, 1999). In the early 1990s, the Chinese housing finance system, manifested by the Housing Provident Fund (HPF) and banking mortgage, had been introduced. The HPF programme raised funds for housing from both individuals and working units; although introduced as a pilot programme in Shanghai only in 1991, it was quickly adopted as a national policy scheme in 1994 (Chen and Deng, 2014). The HPF scheme helped Chinese households to become familiar with and accept the idea of mortgaging future income for today's housing purchase, before the introduction of banking mortgages in the late 1990s. The HPF programme is a significant symbol of housing financialization with Chinese characteristics, as it marks the state's direct involvement in the financialization process of housing.

Trigged by the pressures to cushion economic downturn threats created by the 1997 Asian Financial Crisis, in July 1998 the State Council implemented a radical reform to completely abolish the welfare housing system at a nationwide scale (Chen and Han, 2014). Despite public housing programmes remaining after the 1998 reform, they were now limited to a residual role that primarily targeted only low-income households (Shi, Chen and Wang, 2016). In any case, the landmark 1998 reform decisively ended the dual-track history of the Chinese housing sector, and signalled the overwhelming triumph of the commodification reform of housing in China.

\subsection{Housing assetization accompanied by land assetization (1998-2007)}

After the 1998 reform, almost all public housing stock in the urban areas was privatized and then converted into family assets for urban households. The penetration of mortgage credit in the financing of housing purchase enhanced the asset function of housing. With China's entry to the WTO in 2000, not only was a lasting economic boom kickstarted, but also the credit capital available for investment became cheaper than before. Comparatively, the urban land that under stricter control of local states became increasingly scarce and then precious, especially after the 2004 wave of land management centralization (Huang and Chan, 2018). Thus, the Chinese local states were increasingly considering urban land as their most valuable asset. A series of new 
institutions were created by Chinese entrepreneurial local states to boost the asset functions of land $(\mathrm{Xu}, \mathrm{Yeh}$ and $\mathrm{Wu}, 2009)$. However, the assetization of urban land spurred the increasing assetization of housing, which has made housing affordability an increasingly acute issue in urban China, especially for those new entrants on housing markets (Chen and Han, 2014).

\section{Housing assetization}

Shortly after the 1998 reform, a large-scale privatization of the public housing stock swept across the nation: more than 45.5 million units of public housing were privatized over the period 1998-2005 (see Figure 2). The privatization movement also quickly converted China from a country of public tenants into a super-homeowner society within a few years: the share of public housing tenants in urban residents dropped from more than $60 \%$ in the mid-1990s to below $10 \%$ in 2005 , when the share of owners of private homes rose to $90 \%$ (see Figure 2). Moreover, as the 1998 reform allowed privatized public housing to be traded in the second-hand market almost without restrictions, the privatization of public housing implies the assetization of public housing stock, and then a large wealth transfer (Chen and Han, 2014). Given that the supply of new urban housing has consistently lagged behind the rapid urban population expansion in the urbanization process since 2000, the market value of old urban housing stock has also appreciated greatly, especially in the big cities, which received not only the majority of rural-to-urban migrants, but also most of the city-to-city migrants. The wide availability of privatized public housing stocks as "asset" sources for oldgeneration households' housing purchases is key to understanding the co-existence of an enduring persistence of high price-to-income ratio, alongside a continuous expansion of demand in the Chinese housing market since the 1998 reform. $^{1}$

\footnotetext{
${ }^{1}$ The old generation who obtained homeownership through privatized public housing, although "poor in cash", are "rich in assets", and have high purchasing power in the housing market when they finance the purchase of new homes by cashing the capital gains from old homes. The low home affordability for the new generation and migrants thus co-exists with high expansion of demand for homeownership.
} 


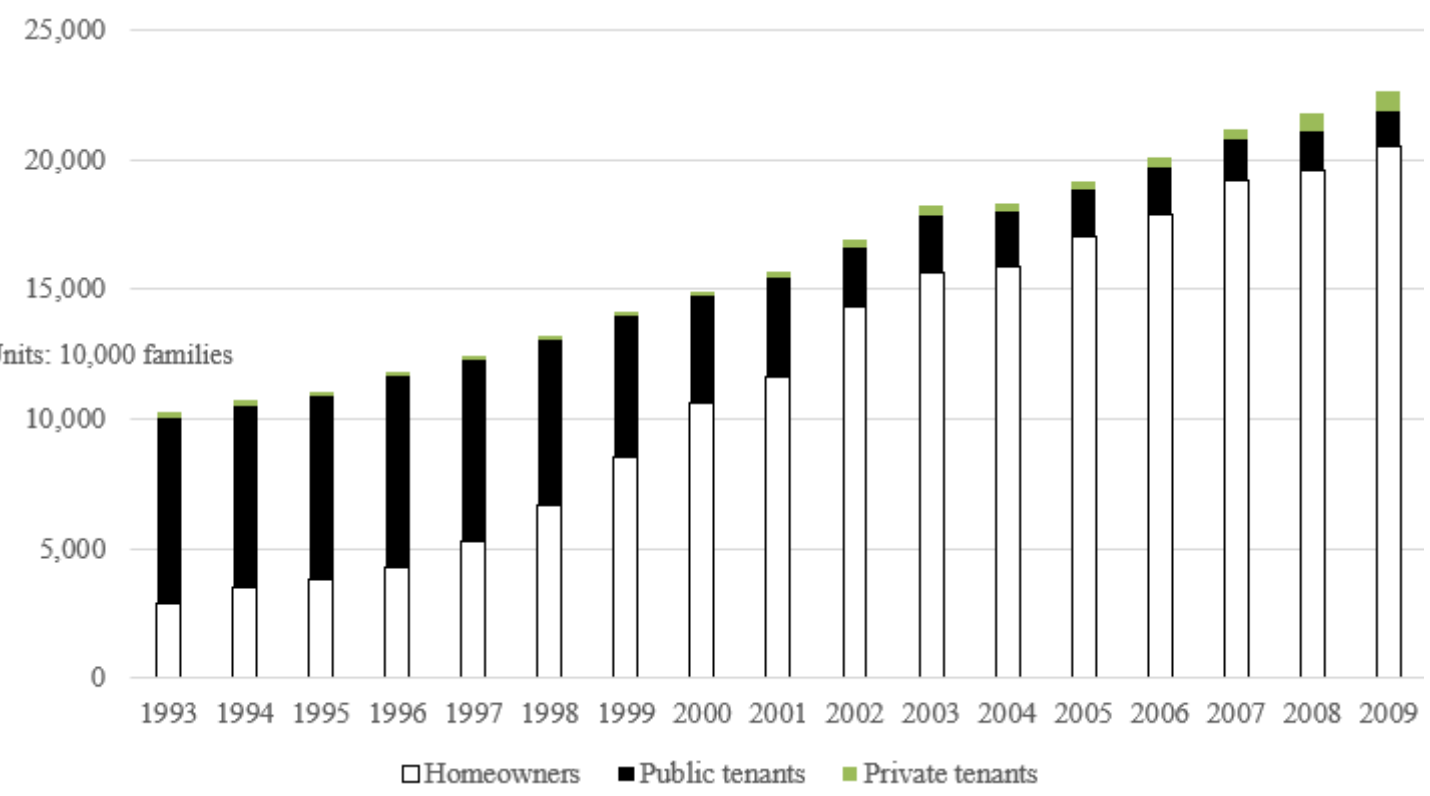

(Figure 2: The housing tenure of Chinese urban households (1993-2009))

Source: Authors' self-computation based on the UHS (Urban Household Survey) database and China Statistics Yearbook of the National Bureau of Statistics of China (NBSC)

The home mortgage business had existed in China before the 1998 reform, but had been growing sluggishly (Deng and Fei, 2012). After the 1998 reform, all commercial banks became actively engaged in issuing home mortgages, and the mortgage loans expanded at a spectacular rate (Deng, Yan and Chen, 2019). The penetration of credit funds in the financing of housing purchases essentially resulted in converting borrowers' future income streams into today's consumption and investment. With future value appreciation being financialized, housing has become not just a commodity, but also the single most important asset for households. The main home-mortgage products in China are not very different from those prevailing in the Western mortgage markets (Deng and Fei, 2012). However, the mortgage interest rate cannot be freely set by banks themselves, but is legally required to be tied to the benchmark loan rate set by the PBC. The PBC also sets the minimum requirements of the down-payment ratio, maximum debt-service ratio, and the longest maturity period of loans, which all banks must comply with (Deng and Fei, 2012). By keeping direct regulation of the home mortgage market, the central government holds an effective instrument to adjust the demand for housing, as well as the distribution of financial credit between the housing and nonhousing sectors. 


\section{Land assetization}

With the growing importance of land sales revenue and land-related fiscal income since the late 1990s, local states began to consider land as their most valuable financial asset (Xu, Yeh and $\mathrm{Wu}, 2009)$. However, until the early 2000s, a dual-track system still dominated in the conveyance of land use-rights in Chinese cities. Most urban stateowned land was still allocated freely by administrative orders; even among those paid conveyances, the majority took place through non-transparent negotiations, with only a small share through open-market auctions or tenders (Lin and Ho, 2005). Nevertheless, as land increasingly became an important asset for local states, the prevalence of underthe-table transactions under the dual-track land conveyance system not only caused rampant corruption, land abuse and misallocation of land resources (Zhao et al., 2020), but also implied great loss of state-owned assets (Xu, Yeh and $\mathrm{Wu}, 2009)$.

To protect the value loss of land assets, the Chinese state enacted a series of institutional configurations of the land conveyancing system in the beginning of 2000s. Since 2001, the administrative allocation of land to commercial projects has been banned. Since 2002, the use-rights of all land intended for business purposes should be conveyed by market means, such as bid invitation, auction or quotation. The Decree issued by MLR in March 2004 (MLR 2004[7]) further stressed that all negotiated conveyances of land use-rights for commercial projects must be banned after 31 August 2004. This regulation was extended to industrial land in 2007 (Huang and Chan, 2018).

The public land banking system (or land reserve system), which has a long history and is still pervasive in Europe, the US and Hong Kong (Carr and Smith, 1975; van Dijk and Kopeva, 2006; Ward and Swyngedouw, 2018), was first introduced as a pilot practice in Guangzhou in 1992 (Huang and Chan, 2018). The first municipal land banking system in China was established in Shanghai in 1996, and has been adopted by most Chinese cities since the early 2000s. Through the municipal land banking system, the land formally becomes a financial asset for the local states. Such public land banking, with local states "purchasing and holding large tracts in places where the development opportunities have not yet arisen" (Xu et al. 2009: 896), precisely treats land as an speculative asset, and constitutes the backbone of the assetization of land in China. The wide prevalence of the land banking system enforces the local states' power 
to control land supply, creates serve "land starve", and propels high housing prices. The expected high inflation of housing in turn makes housing an increasingly attractive asset. In this sense, land assetization has propelled housing assetization.

\section{Financialization of the real estate industry and the presale system}

From the perspective of the real estate industry, the wide prevalence of the presale system (sale before completion) as a major financing mode for housing development is a key factor in the close industry-level interplay between housing financialization and land financialization in China. The presale system, prevailing in Hong Kong and a few other regions, allows purchase payment by households to finance developers in the early stage of development, in a manner similar to "consumer credit"; hence, this reduces financing burdens, as well as the exposure risks of developers (Edelstein, Qian and Tsang, 2010). Under the presale system, both buyers and developers treat housing, even when uncompleted and without use value, as an asset. The direct finance from buyers expands the funding for housing development and thus effectively accelerates housing production, especially in an environment where the cost of debt-financing is high (Leung and Ma, 2013). Although presale agreements for housing purchase contracts had been spread in China in the late 1980s, it became a pervasive practice only after being formally legalized in the 1994 version of the Urban Real Estate Management Rule. The proceeds from presales accounted for more than $40 \%$ of total funding for real estate investment in China in the early 2000s (Leung and Ma, 2013). This pattern persists until today (see Figure 3). Although the presale system itself is also a risk-sharing scheme that buyers engage in voluntarily (Edelstein, Qian and Tsang, 2010), its prevalence in China enables the Chinese real estate industry to be highly financialized from the beginning. 


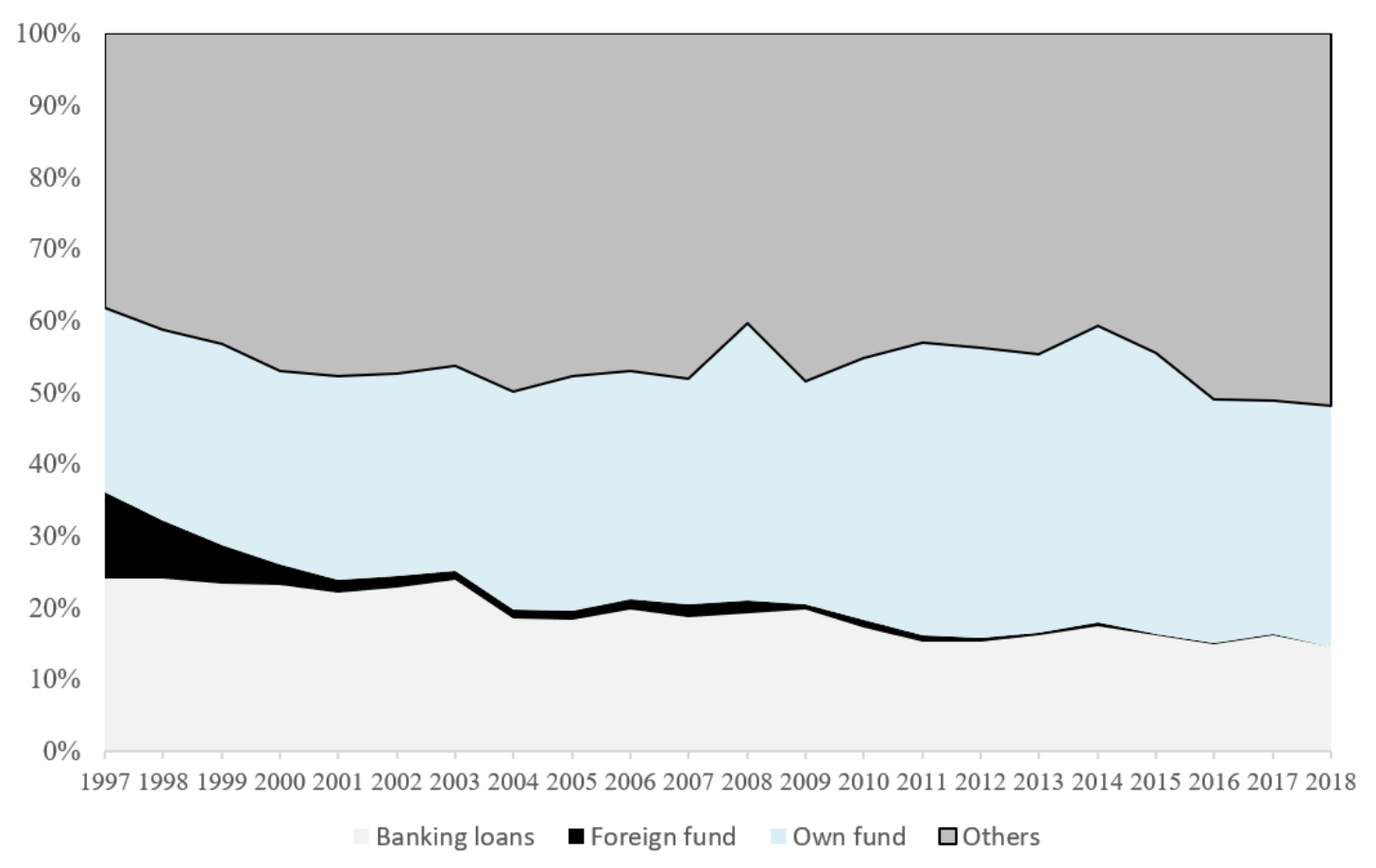

(Figure 3: The funding structure of real estate developers in China (1997-2018))

Source: People's Bank of China, National Bureau of Statistics of China (NBSC)

Note: Major components in the "others" category are buyer's down payment and home mortgage, which would be transferred to developers when housing has not been completed yet, and complement their development funding under the presale system.

4.4 Land capitalization accompanied by deepening housing assetization (2008 to the present)

The financialization of land in China has accelerated since 2008. With pressures to complement funding for the central government's 4 trillion Yuan stimulus package, which responded to the economic downturn risks trigged by the 2008 Global Financial Crisis, the Chinese local states have striven to raise credit capital; and land is the most important channel for them to create new capital (Wu, 2019). In addition, the proactive monetary policy and credit boom under the stimulus package also stimulated the local states to secure credit from financial institutions by using land as collateral. Landcollateralized mortgages and bonds, although they had existed in the early 2000s, substantially expanded only after 2008. Meanwhile, stirred by a series of stimulus policies for purchasing housing, and the credit boom in 2008, housing prices in urban China also experienced a sharp upsurge in 2009, and thus induced more investment demand towards housing assets (Glaeser et al., 2017). The assetization of housing was 
further fuelled by surplus capital that outflowed from the manufacturing industry, when it was plagued with excessive supply due to the global economic recession ( $\mathrm{Wu}, 2015)$. The year 2008 thus marked a new era of financialization in China.

\section{Land capitalization}

In the early 2000s, many Chinese local states had set up various forms of quasifinancing institutions to help mobilize funds for urban development, such as development corporations and local financing platforms (LFP) (Huang and Chan, 2018), more broadly referred to as local government financing vehicles (LGFV) (Wu, 2019). Meanwhile, the local states also began to adopt several new financial instruments that enabled local states to generate development funds through the capitalization of land assets: these included land mortgages, LGFV loans and bonds, and strategic partnerships of development coalitions, such as PPP (public-private partnership) (Huang and Chan, 2018).

The method of land mortgage was first invented in Shanghai's Pudong in the early 1990s, and then became the primary funding resources that allowed Chinese local states or their land development agencies to develop urban land until early 2010s (Wu, 2019). Land mortgages refer to mortgage loans that are commonly issued by commercial banks to land developers, with loans collateralized on undeveloped land that the borrowers have rights to develop and claim profits from. Borrowers of land mortgages can be either property developers or public land developers, including land banking authorities (i.e. land reserve centres, $\mathrm{Wu}, 2019$ ), or other similar local states' land development agencies. A challenge in issuing land mortgages to public land developers is that these borrowers generally do not actually own the title of land collateral. Unlike property developers who have paid a conveyance fee to get the use-rights of land, the public land developers generally do not need to pay any costs to local states to obtain the development rights for undeveloped land. $\mathrm{Wu}$ (2019) suggests that land loan in such situations involves no collateral, but only a guarantee of repayment. Notably, capital for land development is entirely consists of the equity capital of public land developers and money-capital from financial institutions; but the local states do not invest any initial capital during this capital mobilization process. The absence of local states' capital inputs from the land development process that is backed by land mortgages means that this process is "virtual capital circulation"(Wu, 2019). Through land 
mortgage, land development is financed by capitalizing the expected future value of developed land into today's liquid money-capital; the state ownership of land enables the local states to capture future land value appreciation in a land-based capital accumulation process.

The years since 2008 have witnessed the growing importance of urban land, in terms of its use by local states as collateral to raise capital. In 2008, the balance of land mortgages was 1.81 trillion Yuan (collateralized on land of 165,800 hectares), but it soared to 2.59 trillion Yuan (collateralized on land of 217,000 hectares) in 2009, after the massive stimulus plan; it then surged to 9.51 trillion Yuan in 2014 (collateralized on land of 451,000 hectares), and further climbed to 11.33 trillion Yuan (collateralized on land of 490,800 hectares) in 2015 (MLR, 2019). But since the 2007 national regulation of land banking, the utilization of land mortgages has become increasingly difficult (Huang and Chan, 2018). The problems in applying for land mortgages were further amplified by the strict requirement of land banking loans, issued by the PBC in 2012. The central state's tight control of land mortgages was mainly driven by the concern regarding rapidly growing debts, accumulated through land-based borrowing. Thus, although land mortgages expanded substantially between 2008 and 2015, the ratio of land mortgages issued to land reserve centres was consistently kept at around 10-20\% (MLR, 2019). Amidst the growing risks of a national land market downturn in 2014-2015, land mortgages to land reserave centres were completely banned in January 2016 (MoF[2016]4). Since then, the financing needs for land development have to be met through the local state's fiscal expenditure. Meanwhile, since 2011, all land reserve centres have been ordered to restructure themselves in order to be fiscally independent of local government support.

LGFVs have been set up since the early 2000s as commercial entities to borrow funds from the capital market, as the financing conduits of local governments at various levels; this is largely because before 2011, local governments in China were banned by the old Budget Law from borrowing from financial agencies. ${ }^{2}$ Local governments injected

\footnotetext{
${ }^{2}$ In October 2011, the governments of Shanghai and three rich provinces were among the first group of provincial governments that were allowed to issue their own local government bonds in a pilot programme. This programme was extended to a few other provinces in 2013 and 2014.
} 
capital and assets, mostly land assets, into the capital pool of LGFVs, to strengthen their capabilities of capital mobilization in the financial market. The liabilities of LGFVs were guaranteed by local states' assets, and the LGFVs' debt was commonly repaid through local government revenue, and in most cases the revenue from land use-rights conveyance (Huang and Chan, 2018). Besides borrowing loans from banks, LGFVs can also issue bonds to raise funds from the bond market (sometimes referred to as "urban development and investment bonds"). But before 2005, the bond market in China was still at a preliminary stage, and only SOEs owned by the central state or provincial governments could issue corporate bonds. Thus, only eight LGFV bonds were issued between 1999 and 2004, and the total funds raised were 15.6 billion Yuan (Source: iFind database). In 2005, SOEs owned by local states were for the first time allowed to issue corporate bonds on the bond market. The LGFV bonds underwent considerable growth during this period, with the issuance rising from 24.2 billion Yuan in 2005 to 74 billion Yuan in 2008 (Source: iFind database).

LGFV bonds began a further spectacular expansion after 2008, largely urged by the pressures to complement the funding of construction projects, as required by the central government's 4 trillion Yuan stimulus package ( $\mathrm{Wu}, 2019)$. The issuance of LGFV bonds skyrocketed to 282 billion Yuan in 2009, and further rose to 326 billion Yuan in 2011 (Source: iFind database). The number of LGFVs also soared from 306 in 2007 to 8,221 in 2009 (Pan et al., 2017). With substantial credit inflows, LGFVs behaved more aggressively in the land market after 2008: they not only purchased significantly more land from the land market, but also commonly purchased at a price with high premium (Huang and Du, 2018). Land price on average doubled between 2007 and 2010. While higher land prices enhanced the credit-raising capability of local states and their financial agencies on the capital market, they induced a spiral of housing price inflation and boosted the attractiveness of housing as investable assets; this was at the cost of worsening housing affordability among average urban households.

Since 2010, the central government had issued severe warnings regarding the financial risks associated with the steep spiralling of LGFV bonds. However, the issuance of LGFV bonds continued to soar to 829 billion Yuan in 2012 (Source: iFind database). The central state's measures to cool down the LGFV bond market led the bond issuance in 2013 to be stabilized at 828 billion Yuan (Source: iFind database). The No.32 Audit 
Report released by the NAO (National Audit Office) in December 2013 suggests that the outstanding debt balance of LGFVs at the end of June 2013 had declined to 4,075.5 billion Yuan, and its share of the local governments' total debt was 37.44\% (NAO, 2013). In October 2014, the State Council set out an order to reshuffle the management of local governments' debt: while imposing a maximum quota on the debt amount that was potentially accrued by each local government, and prohibiting the local governments' debt borrowing through the LFGVs henceforward, the order also encouraged the local governments to issue bonds with their own liability (SC[43]2014). With the Budget Law amended, since January 2015, all provincial governments have been authorized to issue local government bonds on the bond market.

With the embargo on land mortgages to land reserve centres since 2016 and the prohibition of borrowing through LFGVs since 2014, this appears to signal the end of local states' capital accumulation strategy through mortgaging land and capitalization of land assets. However, the State Council has since 2014 attempted to promote a collaborative financing model of urban development that could reduce local debt accumulation; the PPP is a key form of this model. Nevertheless, in many cases this new urban financing model still relies on either the capitalization of future potential returns of land development (Huang and Chan, 2018), or on the capitalization of future income streams of urbanized use-value.

\section{Deepening housing assetization}

In 2009 alone, even assessed in terms of the official statistical data without quality adjustment, the average urban housing price in most big cities in China increased by almost 50\% (Source: iFind database). Vacancies in China's urban housing stock have increased sharply after 2009, and are high and pervasive now (Glaeser et al., 2017). A more recent survey report released by the CHFS (China Household Finance Survey) finds that the level of vacancies in China's urban housing stock increased from $18.4 \%$ in 2011 to $21.4 \%$ in 2017 (CHFS, 2018). This survey also finds the share of first-time homebuyers was only $12.8 \%$, while the share of homebuyers with at least three homes was $21.5 \%$ in the third quarter of 2018 (CHFS, 2018). The coexistence of escalating price inflation and a high level of housing vacancies, together with strong demand for 
multiple homes, vividly shows that many Chinese households are increasingly treating housing as an asset rather than a commodity.

The expanding pursuit of housing as an asset could not have been realized without more assistance from financial instruments. The figure below suggests that home mortgages in China grew more rapidly after 2008. The percentage of home mortgage balance against GDP increased from 10.48\% in 2008 to $28.60 \%$ in 2018 (see Figure 4). Similar trends are observed for the percentage of home mortgage balance in relation to household savings and urban household income; these were $15.38 \%$ and $34.02 \%$ respectively in 2008, but soared to $35.96 \%$ and $78.91 \%$ respectively in 2018 (see Figure 4).

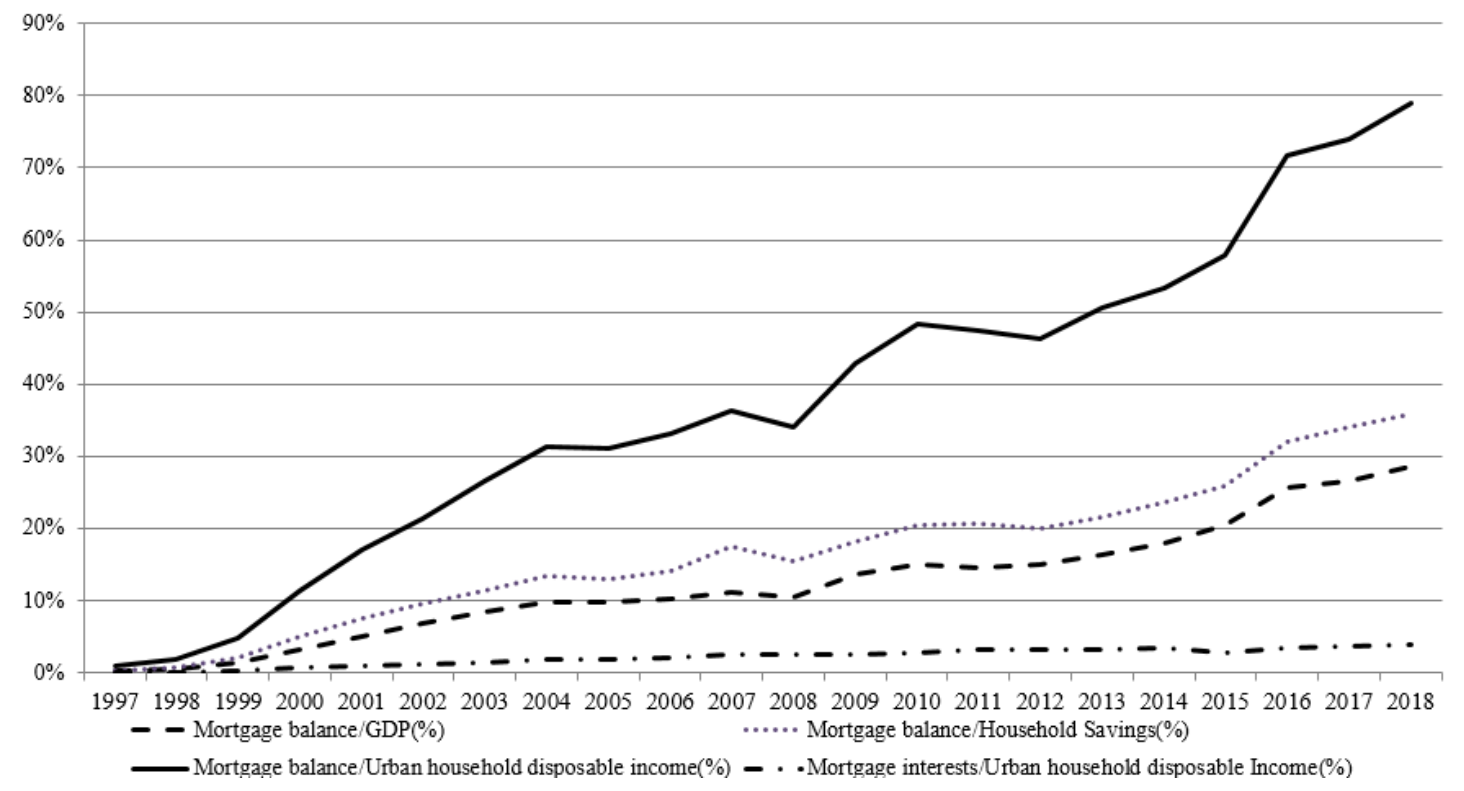

(Figure 4: The Housing Mortgage Balance in China (1997-2018))

Source: People's Bank of China, National Bureau of Statistics of China (NBSC)

Furthermore, according to CHFS, the ratio of Chinese households with mortgaged homeownership in the survey year rises from $6.9 \%$ in 2011 to $9.4 \%$ in 2015 (CHFS, 2017). The current level is similar to most post-socialist CEE countries, which is averaged at 9.9\% in 2011 (Stephens, Lux and Sunega, 2015). Compared to most advanced market countries, with an average ratio of home mortgage to GDP of around $40 \%$ to $50 \%$ (Warnock and Warnock, 2008), the relative size of the home mortgage balance in China is still moderate. At the household level, similar those CEE post- 
socialist economies (Stephens, Lux and Sunega, 2015), the Chinese housing regime shows an emerging financialization trend rather than a well-financialized status. Nonetheless, the rapid growth in home mortgages deserves attention.

Notably, the securitization of housing mortgages in China is very small compared to the size of housing mortgage stock. Although over the last few years the Chinese RMBS (residential mortgage-backed securities) market has skyrocketed, and in 2018 alone the new issuance of RMBS was 3.4 times that in previous year (CCDC, 2019), securitization still provides only $2.9 \%$ of the funding of home mortgages in China. This ratio is much lower than the average level of advanced economies, and even lags behind many CEE post-socialist economies (Hegedüs and Struyk, 2006; Stephens, Lux and Sunega, 2015). The relatively small scale of mortgage securitization in China is perhaps due to the major providers of Chinese mortgage funding being state-owned banks who are enjoying a preferential position in attracting deposit savings, and are thus not in urgent need of a liquidity facility to refinance their mortgage loans. However, it should be noted that residential mortgage securitization is a key force in promoting asset securitization and accelerating the financialization of the general economy in China. ${ }^{3}$

\section{Interplay between housing financialization and land financialization in China}

At the start of this analysis, it is crucial to note the heterogeneity of land in capital generation: only land for residential and commercial use has been capitalized, and not industrial land. The official statistical data from NBSC reveal that between 1998 and 2018, the average price of land use-rights purchased by developers skyrocketed from $371 \mathrm{Yuan} / \mathrm{m}^{2}$ to $12,486 \mathrm{Yuan} / \mathrm{m}^{2}$. The data also suggest that the revenues of sales of land use-rights in China have grown at a spectacular speed since the early $21^{\text {st }}$ century and reached 6.5 trillion Yuan in 2018, roughly accounting for $25 \%$ of local states' total incomes in that year. But note that nearly all of the price inflation of land use-rights is due to commercial and residential land, while the price of industrial land is almost same as two decades ago.

\footnotetext{
${ }^{3}$ The unpaid balance of RMBS was 748 billion Yuan at the end of 2018 , accounting for $68 \%$ of the unpaid balance of Chinese bond-form ABS (asset-backed securities) (CCDC, 2019).
} 
The phenomenon "land-finance reliance" in China, which refers to the fact that Chinese local states' public finance has relied heavily on land revenue and land-related fiscal income since the mid-1990s, has been extensively discussed in the literature (Wang and Ye, 2016; Hu and Qian, 2017). However, as pointed out by Wu (2019), revenue generation is only one of many motivations underlying the Chinese local states' land management. Through LGFVs and other financing platforms, the debt that Chinese local states are responsible for repaying reached the substantial amount of 16.5 trillion Yuan at the end of 2017, and most of this debt is pledged on future expected revenue from land use-rights sales (source: iFind database). Thus, with financialized land as collateral, local governments are greatly expanding their capital to invest in the economy today.

On the one hand, the capitalization functions of residential and commercial land are based on the precondition that property built upon such land could be converted into investable assets with high liquidity, and then the invested capital on land development could be easily cashed. On the other hand, industrial land in China has been generally conveyed with nearly zero price or even a negative price - where the latter means that the industrial firms who purchased industrial land were usually granted generous subsidies from the local states, which compete fiercely to attract profitable industrial investment that could contribute jobs, fiscal revenue and GDP (Su and Tao, 2017; Wu, 2019). Chinese municipal governments endeavour to maximize land-based funding strategically rather than short-sightedly (Hu and Qian, 2017; Huang and Du, 2018). It has been widely suggested that Chinese local states leverage the land revenue to promote industrial agglomeration, through the "industrial linkage and spill-over" mechanism; this involves investing in infrastructure construction and subsidizing industrial investment (including the service industry) ( $\mathrm{Su}$ and Tao, 2017). The entrepreneurial nature of local states in China, however, is said to be rooted in the Chinese-style authoritative regime, which is compelled to prop up economic prosperity, given that economic performance constitutes the primary basis of its legitimacy (Yang and Zhao, 2015). Thus, for these entrepreneurial local states, land is "used as a leverage for generating development finance rather than just fiscal income" (Wu, 2019: 2). Nonetheless, the subsidies for industrial agglomeration and infrastructure investments are generally financed from the local states' land-based revenue and land-collateralized 
borrowing, which are associated with residential and commercial land (Wang and Ye, 2016).

To reap more capital from land capitalization, the local states always have strong incentives to uphold the price appreciation trend of housing, so that the housing asset can maintain its status as the most attractive investment outlet for households (Wu et al., 2020). Through tactics such as construction land quotas, land supply plans, constraints on the allowed FAR (floor area ratio) of land parcel, land banking, the investment strategy of LGFVs, and urban planning, the Chinese local states skilfully manipulate the value inflation expectation of housing assets, in order to sustain a spiralling rise of housing prices (Hu and Qian, 2017; Han, Zhang and Zheng, 2020). The complete state-ownership of urban land, amplified by the state monopoly of land supply, gives local states both incentives and the capability to launch a property-driven urban construction boom. Thus, housing assetization and land capitalization are deeply intertwined with each other, and cannot be separated if we want to understand the whole picture of China's financialized urban growth model.

It is important to note that since the mid-2000s, the constraints of urban land resources under the "red-line" protection of rural land, as well as the rapidly rising cost of land acquisition in the forms of compensation and demolition costs, have reduced the contribution of net land revenue to local public finance ( $\mathrm{Wu}, 2019)$. Further, the mounting surplus of manufacturing capability, following the 4 trillion Yuan stimulus plan implemented in 2008 (Bai, Hsieh and Song, 2016), has also reduced the local states' incentives to supply more industrial land. These factors have jointly induced a major shift in the local states' mode of land management operation: where they previously attempted to maximize land revenue, they now enhance the capital value of land reserve stock, to leverage more funding from the financial market. This, however, implies that local states inherently have low incentives to expand land supply, but have high incentives to boost land price inflation; an expectation that is commonly shared by the public (Wang and Ye, 2016; Huang and Du, 2018). This leads to a sustained upward trend in housing prices, but also to growing risks of a property bubble burst.

The Chinese state also frequently deploys the interplay of housing financialization and land financialization as a tool to combat the crisis of oversupply of production 
capacities. As noted above, the Chinese state's response to both the 1997 Asian Financial Crisis and the 2008 Global Financial Crisis was to trigger a real estate boom and then increase the profitability of investment in the built environment, so that the massive surplus capital and labour could find outlets there (Wu, 2015). The local states were particularly active in boosting housing markets whenever there were signs of prices dipping, and their policies were generally received positively by urban homeowners and business entrepreneurs (Glaeser et al., 2017). This is not surprising. Under state entrepreneurialism, which governs the urban space by combining planning centrality and market instruments (Wu, 2018), stakeholder coalitions formed by local states, developers, financial agencies, homeowners, and other reapers of land value appreciation, are transforming the landscape in Chinese cities. Although rural-to-urban migration in China has somewhat slowed down in recent years, the continuing inflow of migrants from small and medium cities to leading cities means that housing in these cities is still very scarce, and it is thus one of the most attractive target outlets for financial capital.

\section{Concluding remarks}

Through analysing the evolving process of the financialization of housing and land in China, this paper demonstrates that housing financialization stimulates households' demand for housing assets, and land financializaton expands the capability to supply housing as a household asset to meet this growing demand. With the investment of "landed" capital in the production of housing assets and the accrued profits, the local states accumulate more capital, in order to promote industrial agglomeration, to invest in the built environment, to improve urban amenity, and to produce more urban space. The increased attractiveness of cities again boosts more investment demand for local housing assets, thereby raising the land value and facilitating further land capitalization. Thus, housing assetization and land capitalization are engaged in this self-enhancing circle.

However, this paper also points out that the self-reinforcing circle of housing assetization and land capitalization in China is built on a series of unique Chinese institutional settings, which include inter-city competition, local state ownership of urban land in China, and a number of financial conduits owned by local states. Inter- 
city competition stimulates the entrepreneurial incentives of local states, and the supply monopoly of urban land allows entrepreneurial local states to use land as a financial asset, in order to raise capital through a variety of stated-owned financial conduits. This situation is very different from Western countries, where the state generally cannot use public land as a financial asset directly, but instead can only create conditions to facilitate such use by the private sector (Christophers, 2017). Driven by the diverse motivations of different levels of the entrepreneurial state, as well as the profit-seeking of investors, pro-growth coalitions between local government, developers and government enterprise are being formed during the financialization process of the housing-land regime, and these exert powerful influences on the Chinese-style financialized urban growth model.

Nevertheless, the current housing-land financialization model in China is not only producing a severe affordability crisis that threatens social stability; it is also sensitive to population ageing, as well as to a productivity slowdown. The self-amplifying feedback cycle between finance and landed property, as discussed by Ryan-Collins (2020), is entirely built on the expectation of the future value appreciation of urban space; but this prospect will significantly fade when the population declines and economic growth is sluggish. Whether and how the Chinese housing-land sector can be safely de-financialized, in order to avoid the burst of a property bubble such as Japan experienced in the early 1990s, are critically important questions; but these must be left for future research.

\section{Acknowledgements}

The authors thank the financial supports from the NSFC-ESRC Joint Funding (NSF71661137004, ES/P003435/1) and National Natural Science Foundation of China (NSF71573166; NSFC71974125).

\section{References}

Aalbers, M. B. (2008) 'The financialization of home and the mortgage market crisis', Competition \& Change, 12(2), pp. 148-166. doi: 10.1179/102452908X289802. 
Aalbers, M. B. (2017) 'The Variegated Financialization of Housing', International Journal of Urban and Regional Research, 41(4), pp. 542-554. doi: 10.1111/1468-2427.12522.

Aalbers, M. B. and Christophers, B. (2014) 'Centring Housing in Political Economy', Housing, Theory and Society, 31(4), pp. 373-394. doi: 10.1080/14036096.2014.947082.

Arrighi, G. (1994) The Long Twentieth Century: Money, Power, and the Origins of Our Times. London and New York: Verso. Available at: https://quod.lib.umich.edu/cgi/t/text/textidx?c=acls;cc=acls;view=toc;idno=heb30939.0001.001.

Bai, C.-E., Hsieh, C.-T. and Song, Z. M. (2016) 'The Long Shadow of a Fiscal Expansion', NBER Working Paper Series. Cambridge, MA, No. 22801. doi: 10.3386/w22801.

Bian, F. (2010) The Chinese estate industry these years. Hangzhou: Zhejiang University Press. Available at: https://item.jd.com/10082998.html.

Birch, K. (2017) 'Rethinking Value in the Bio-economy: Finance, Assetization, and the Management of Value', Science, Technology, \& Human Values, 42(3), pp. 460-490. doi: $10.1177 / 0162243916661633$.

Bonizzi, B. (2013) 'Financialization in Developing and Emerging Countries: A Survey', International Journal of Political Economy, 42(4), pp. 83-107. doi: 10.2753/IJP08911916420405.

Boyer, R. (2000) 'Is a Finance-led growth regime a viable alternative to Fordism? A preliminary analysis', Economy and Society, 29(1), pp. 111-145. doi: $10.1080 / 030851400360587$.

Buckley, M. and Hanieh, A. (2014) 'Diversification by Urbanization: Tracing the PropertyFinance Nexus in Dubai and the Gulf', International Journal of Urban and Regional Research, 38(1), pp. 155-175. doi: 10.1111/1468-2427.12084.

Carr, J. and Smith, L. B. (1975) 'Public Land Banking and the Price of Land', Land Economics, 51(4), pp. 316-330. Available at: http://www.jstor.org/stable/3144949?origin=crossref.

CCDC (2019) China Asset Securitization Report 2018. Beijing. Available at: https://www.chinabond.com.cn/cb/cn/yjfx/zzfx/nb/20190116/150712957.shtml.

Chen, J. and Deng, L. (2014) 'Financing Affordable Housing Through Compulsory Saving: The Two-Decade Experience of Housing Provident Fund in China', Housing Studies, 29(7), pp. 937-958. doi: 10.1080/02673037.2014.923088. 
Chen, J. and Han, X. (2014) 'The Evolution of Housing Market and Its Socio-economic Impacts in Post-Reform China: A Survey of the Literature', Journal of Economic Survey, 28(4), pp. 652-670. doi: 10.1111/joes.12076.

CHFS (2017) The Report on Chinese Households' Housing Credit. Chengdu. Available at: http://finance.sina.com.cn/china/2017-01-04/doc-ifxzczsu6811968.shtml (Accessed: 14 January 2017).

CHFS (2018) The Report on Housing Vacancy in China 2017. Chengdu. Available at: https://chfs.swufe.edu.cn.

Christophers, B. (2017) 'The State and Financialization of Public Land in the United Kingdom', Antipode, 49(1), pp. 62-85. doi: 10.1111/anti.12267.

Deng, L., Yan, X. and Chen, J. (2019) 'Housing affordability, subsidized lending and crosscity variation in the performance of China's housing provident fund program', Housing Studies, 34, pp. 1-24. doi: 10.1080/02673037.2019.1585521.

Deng, Y. and Fei, P. (2012) 'Mortgage Market, Character and Trends: China', in Smith, S. J. B. T.-I. E. of H. and H. (ed.) International Encyclopedia of Housing and Home. San Diego: Elsevier, pp. 422-433. doi: 10.1016/B978-0-08-047163-1.00152-1.

van Dijk, T. and Kopeva, D. (2006) 'Land banking and Central Europe: future relevance, current initiatives, Western European past experience', Land Use Policy, 23(3), pp. 286301. doi: 10.1016/j.landusepol.2004.07.005.

Ding, C. (2003) 'Land policy reform in China: assessment and prospects', Land Use Policy, 20(2), pp. 109-120. doi: 10.1016/S0264-8377(02)00073-X,.

Doling, J. and Ronald, R. (2014) Housing East Asia: Socioeconomic and Demographic Challenges. Edited by J. Doling and R. Ronald. Hampshire: Palgrave Macmillan. Available at: http://www.amazon.com/gp/product/0230358586?selectObb=new.

Duckett, J. (1996) 'The emergence of the entrepreneurial state in contemporary China', The Pacific Review, 9(2), pp. 180-198. doi: 10.1080/09512749608719178.

Edelstein, R. H., Qian, W. and Tsang, D. (2010) 'How Do Institutional Factors Affect International Real Estate Returns?', Journal of Real Estate Finance and Economics, 43(12), pp. 130-151. doi: 10.1007/s11146-010-9245-4.

Epstein, G. A. (2005) Financialization and the world economy. Edited by G. A. Epstein. 
Northampton: Edward Elgar Publishing. Available at: https://www.eelgar.com/shop/financialization-and-the-world-economy.

Fernandez, R. and Aalbers, M. B. (2016) 'Financialization and housing: Between globalization and varieties of capitalism', Competition \& Change, 20(2), pp. 71-88. doi: $10.1177 / 1024529415623916$.

Froud, J. et al. (2000) 'Shareholder value and Financialization: consultancy promises, management moves', Economy and Society, 29(1), pp. 80-110. doi: $10.1080 / 030851400360578$.

García-Lamarca, M. and Kaika, M. (2016) “"Mortgaged lives”: the biopolitics of debt and housing financialisation', Transactions of the Institute of British Geographers, 41(3), pp. 313-327. doi: 10.1111/tran.12126.

Glaeser, E. L. et al. (2017) 'A Real Estate Boom with Chinese Characteristics', Journal of Economic Perspectives, 31(1), pp. 93-116. doi: 10.1257/jep.31.1.93.

Gotham, K. F. (2006) 'The Secondary Circuit of Capital Reconsidered: Globalization and the U.S. Real Estate Sector', American Journal of Sociology, 112(1), pp. 231-275. doi: $10.1086 / 502695$.

Gotham, K. F. (2009) 'Creating Liquidity out of Spatial Fixity: The Secondary Circuit of Capital and the Subprime Mortgage Crisis', International Journal of Urban and Regional Research, 33(2), pp. 355-371. doi: 10.1111/j.1468-2427.2009.00874.x.

Han, W., Zhang, X. and Zheng, X. (2020) ‘Land use regulation and urban land value: Evidence from China', Land Use Policy, 92, p. 104432. doi: 10.1016/j.landusepol.2019.104432.

Harvey, D. (1985) The Urbanization of Capital: Studies in the History and Theory of Capitalist Urbanization, Science and Society. New York: Guilford Press. Available at: http://philpapers.org/rec/HARTUO-14.

Hegedüs, J. and Struyk, R. J. (2006) Housing finance: new and old models in central Europe, Russia and Kazakhstan. Edited by J. Hegedüs and R. J. Struyk. Budapest: Open Society Institute. Available at: http://pdc.ceu.hu/archive/00005333/ (Accessed: 12 July 2011).

Hu, F. Z. and Qian, J. (2017) 'Land-based finance, fiscal autonomy and land supply for affordable housing in urban China: A prefecture-level analysis', Land Use Policy, 69(5), pp. 454-460. doi: 10.1016/j.landusepol.2017.09.050. 
Huang, D. and Chan, R. C. K. (2018) 'On "Land Finance” in urban China: Theory and practice', Habitat International, 75(1), pp. 96-104. doi: 10.1016/j.habitatint.2018.03.002.

Huang, Z. and Du, X. (2018) 'Holding the market under the stimulus plan: Local government financing vehicles' land purchasing behavior in China', China Economic Review, 50(1), pp. 85-100. doi: 10.1016/j.chieco.2018.04.004.

Kaika, M. and Ruggiero, L. (2016) 'Land Financialization as a "lived" process: The transformation of Milan's Bicocca by Pirelli', European Urban and Regional Studies, 23(1), pp. 3-22. doi: 10.1177/0969776413484166.

Krippner, G. R. (2005) 'The financialization of the American economy', Socio-Economic Review, 3(2), pp. 173-208. doi: 10.1093/SER/mwi008.

Lapavitsas, C. (2011) 'Theorizing financialization', Work, Employment and Society, 25(4), pp. 611-626. doi: 10.1177/0950017011419708.

Lefebvre, H. (1976) 'Reflections on the Politics of Space', Antipode. Edited by M. J. Enders, 8(2), pp. 30-37. doi: 10.1111/j.1467-8330.1976.tb00636.x.

Lefebvre, H. (1991) The Production of Space. Oxford: Blackwell Publishers Ltd.

Lefebvre, H. (2003) The Urban Revolution. Minneapolis: University of Minnesota Press. Available at: https://muse.jhu.edu/book/28861.

Leung, B. Y. P. and Ma, A. S. C. (2013) 'Exploration of the presale property market in China from an institutional perspective', International Journal of Strategic Property Management, 17(3), pp. 248-262. doi: 10.3846/1648715X.2013.822435.

Lin, G. C. S. and Ho, S. P. S. (2005) 'The State, Land System, and Land Development Processes in Contemporary China', Annals of the Association of American Geographers, 95(2), pp. 411-436. doi: 10.1111/j.1467-8306.2005.00467.x.

Lin, G. C. S. and Yi, F. (2011) 'Urbanization of Capital or Capitalization on Urban Land? Land Development and Local Public Finance in Urbanizing China', Urban Geography, 32(1), pp. 50-79. doi: 10.2747/0272-3638.32.1.50.

Martin, R. (2002) The Financialization of Daily Life. Philadelphia: Temple University Press. Available at: https://muse.jhu.edu/book/9693.

Marx, K. (1887) Capital: A Critique of Political Economy. Moscow: Progress Publishers. Available at: https://www.marxists.org/archive/marx/works/1867-c1/index.htm. 
MLR (2019) MLR Yearbooks of Land Resources. Beijing: Ministry of Land Resources of PRC.

Montgomerie, J. (2007) Financialization and consumption: an alternative account of rising consumer debt levels in Anglo-America. Available at: https://www.escholar.manchester.ac.uk/uk-ac-man-scw:181191.

NAO (2013) The Audit Results of National Governmental Debt (Audit Report No.2013-32), The Official Website of National Adudit Office of China. Beijing. Available at: http://www.audit.gov.cn/n1992130/n1992150/n1992500/3432077.html.

Ouma, S., Johnson, L. and Bigger, P. (2018) 'Rethinking the financialization of "nature", Environment and Planning A: Economy and Space. SAGE Publications Ltd, 50(3), pp. 500-511. doi: 10.1177/0308518X18755748.

Pan, F. et al. (2017) 'Developing by borrowing? Inter-jurisdictional competition, land finance and local debt accumulation in China', Urban Studies, 54(4), pp. 897-916. doi: $10.1177 / 0042098015624838$.

Qun, W., Li, Y. and Yan, S. (2015) 'The incentives of China's urban land finance', Land Use Policy, 42(1), pp. 432-442. doi: 10.1016/j.landusepol.2014.08.015.

Rouwendal, J. (1998) 'On Housing Services', Journal of Housing Economics, 7(3), pp. 218 242. doi: 10.1006/jhec.1998.0233.

Ryan-Collins, J. (2020) 'Breaking the housing-finance cycle: Macroeconomic policy reforms for more affordable homes', Environment and Planning A: Economy and Space. doi: 10.1177/0308518X19862811.

Shen, J. and Wu, F. (2017) 'The Suburb as a Space of Capital Accumulation: The Development of New Towns in Shanghai, China', Antipode, 49(3), pp. 761-780. doi: 10.1111/anti.12302.

Shi, W., Chen, J. and Wang, H. (2016) 'Affordable housing policy in China: New developments and new challenges', Habitat International, 54(3), pp. 224-233. doi: 10.1016/j.habitatint.2015.11.020.

Shin, H. B. (2009) 'Residential Redevelopment and the Entrepreneurial Local State: The Implications of Beijing's Shifting Emphasis on Urban Redevelopment Policies', Urban Studies, 46(13), pp. 2815-2839. doi: 10.1177/0042098009345540.

Stephens, M., Lux, M. and Sunega, P. (2015) 'Post-Socialist Housing Systems in Europe: Housing Welfare Regimes by Default?', Housing Studies, 30(8), pp. 1210-1234. doi: 
10.1080/02673037.2015.1013090.

Su, F. and Tao, R. (2017) 'The China model withering? Institutional roots of China's local developmentalism', Urban Studies, 54(1), pp. 230-250. doi: 10.1177/0042098015593461.

Wang, W. and Ye, F. (2016) 'The Political Economy of Land Finance in China', Public Budgeting \& Finance, 36(2), pp. 91-110. doi: 10.1111/pbaf.12086.

Wang, Y. (2015) 'The rise of the "shareholding state": financialization of economic management in China', Socio-Economic Review, 13(3), pp. 603-625. doi: 10.1093/ser/mwv016.

Wang, Y. P. and Murie, A. (1996) 'The Process of Commercialisation of Urban Housing in China', Urban Studies, 33(6), pp. 971-989. doi: 10.1080/00420989650011690.

Wang, Y. P. and Murie, A. (1999) 'Commercial housing development in urban China', Urban Studies, 36(9), pp. 1475-1494. Available at: http://usj.sagepub.com/content/36/9/1475.short (Accessed: 18 November 2011).

Ward, C. and Aalbers, M. B. (2016) 'Virtual special issue editorial essay: "The shitty rent business": What's the point of land rent theory?', Urban Studies, 53(9), pp. 1760-1783. doi: $10.1177 / 0042098016638975$.

Ward, C. and Swyngedouw, E. (2018) 'Neoliberalisation from the Ground Up: Insurgent Capital, Regional Struggle, and the Assetisation of Land', Antipode, 50(4), pp. 1077-1097. doi: $10.1111 /$ anti.12387.

Warnock, V. C. and Warnock, F. E. (2008) 'Markets and housing finance', Journal of Housing Economics, 17(3), pp. 239-251. doi: 10.1016/j.jhe.2008.03.001.

Weber, R. (2010) ‘Selling City Futures: The Financialization of Urban Redevelopment Policy’, Economic Geography, 86(3), pp. 251-274. doi: 10.1111/j.1944-8287.2010.01077.x.

Wu, F. (2015) 'Commodification and housing market cycles in Chinese cities', International Journal of Housing Policy, 15(1), pp. 6-26. doi: 10.1080/14616718.2014.925255.

Wu, F. (2018) 'Planning centrality, market instruments: Governing Chinese urban transformation under state entrepreneurialism', Urban Studies, 55(7), pp. 1383-1399. doi: $10.1177 / 0042098017721828$.

Wu, F. (2019) 'Land financialisation and the financing of urban development in China', Land Use Policy, p. 104412. doi: 10.1016/j.landusepol.2019.104412. 
Wu, F. et al. (2020) 'Assetization: The Chinese Path to Housing Financialization', Annals of the American Association of Geographers, forthcomin, pp. 1-17. doi: $10.1080 / 24694452.2020 .1715195$.

Wu, Y. et al. (2014) 'Industrial land price and its impact on urban growth: A Chinese case study', Land Use Policy, 36, pp. 199-209. doi: 10.1016/j.landusepol.2013.08.015.

Xu, J., Yeh, A. G.-O. and Wu, F. (2009) 'Land Commodification: New Land Development and Politics in China since the Late 1990s', International Journal of Urban and Regional Research, 33(4), pp. 890-913. doi: 10.1111/j.1468-2427.2009.00892.x.

Xue, D. and Wu, F. (2015) 'Failing entrepreneurial governance: From economic crisis to fiscal crisis in the city of Dongguan, China', Cities, 43(1), pp. 10-17. doi: 10.1016/j.cities.2014.11.005.

Yang, H. and Zhao, D. (2015) 'Performance Legitimacy, State Autonomy and China's Economic Miracle', Journal of Contemporary China, 24(91), pp. 64-82. doi: 10.1080/10670564.2014.918403.

Zhao, R. et al. (2020) 'The impact of anti-corruption measures on land supply and the associated implications: The case of China', Land Use Policy, 95, p. 104605. doi: 10.1016/j.landusepol.2020.104605. 